\title{
SOCIALINIŲ PASLAUGŲ PRIEINAMUMAS PSICHOSOCIALINĘ NEGALIĄ TURINTIEMS ASMENIMS: ANYKŠČIŲ RAJONO ATVEJIS
}

\author{
Odeta Merfeldaitė, Gintarẻ Sabaliauskienė, Laura Gardziulevičienė \\ Mykolo Romerio universitetas (Lietuva)
}

\begin{abstract}
Anotacija
Sprendžiant psichosocialinę negalią turinčių asmenų problemas ir tenkinant jų poreikius, vienas pagrindinių pagalbos šaltinių yra socialinès paslaugos. Asmenys, turintys psichosocialinę negalią, vis dar patiria socialinę atskirtị, be to, trūksta jiems skirtų paslaugų. Lietuvoje vyraujanti socialinių paslaugų teikimo sistema yra labiau bendro pobūdžio, ji mažiau orientuota ị asmens, turinčio negalią, individualius poreikius. Siekiant užtikrinti asmens, turinčio psichosocialinę negalią, funkcionavimą visuomeniniame gyvenime, būtini pokyčiai teikiant socialines paslaugas. Svarbus aspektas - tarpinstitucinis bendradarbiavimas visais lygmenimis. Lietuvoje už socialinių paslaugų teikimą atsakingos savivaldybès. Straipsnyje analizuojame socialinių paslaugų prieinamumą psichosocialinę negalią turintiems asmenims, remiantis atvejo analize. Tyrimo rezultatai leidžia atskleisti asmenų, turinčių psichosocialinę negalią, pagalbos prieinamumą ir funkcionavimą visuomeniniame gyvenime. Tyrimo rezultatai praktiškai padès tobulinti asmenims, turintiems psichosocialinę negalią, skirtų paslaugu prieinamumą socialinès ịtraukties bendruomenèje kontekste.

PAGRINDINIAI ŽODŽIAI: socialinės paslaugos, paslaugų prieinamumas, psichosocialinè negalia, socialinè įtrauktis bendruomenèje.
\end{abstract}

\begin{abstract}
One of the main sources of help in solving the problems of people with psycho-social disabilities and meeting their needs is the social services. Individuals with psycho-social disabilities still experience social exclusion and a lack of services. The prevailing system of social services in Lithuania is more general, and less focused on the individual needs of a person with a disability. In order to ensure the functioning of a person with a psycho-social disability in public life, changes in the provision of social services are necessary. An important aspect is inter-institutional cooperation at all levels. In Lithuania, local government is responsible for the provision of social services. In this article, we analyse the accessibility of social services for people with psycho-social disabilities based on a case study. The results of the research reveal the availability and functioning of help for people with psycho-social disabilities in community life. The practical significance of the study is useful for improving the accessibility of services for people with psycho-social disabilities in the context of social inclusion in the community.

KEY WORDS: social services, access to services, psycho-social disability, social inclusion in the community.
\end{abstract}

DOI: http://dx.doi.org/10.15181/tbb.v87i2.2321

\section{Ivadas}

Socialinès paslaugos yra viena iš socialinès apsaugos sistemos dalių. Jų teikimo tikslas - grąžinti žmogui gebejimą pasirūpinti savimi, skatinti jo dalyvavimą 
visuomeneje, kai jis pats nepajejgia to padaryti. Socialinès pagalbos procesai nevyksta savaime, tai priklauso nuo bendruomenès požiūrio, vietos gyventojų, gyvenamos aplinkos socialinio klimato ir institucijų pagalbos (O’Donovan, 2021). Psichosocialinę negalią turinčių asmenų dalyvavimas bendruomenės gyvenime yra svarbus paslaugų teikèjų ir politikos formuotojų tikslas (Simplica ir kt., 2015).

Temos aktualumą pagrindžia psichosocialinę negalią turinčių asmenų ,portreto" pokyčiai. 2021 m. kovo mèn. Europos Komisija patvirtino 2021-2030 m. neigaliụjų teisių strategiją, kurioje teigiama, kad žmonès, turintys negalią, turi teisę gyventi savarankiškai ir būti įtraukti ị bendruomenę, pasirinkti gyvenimo vietą, su kuo ir kaip gyventi. Pažymima, kad pagrindinès paramos paslaugos turi būti ịtraukios ir prieinamos neigaliems žmonèms, atsižvelgiant ị lyčių bei kultūros aspektus (COM, 2021). Lietuva 2010 m. ratifikavo Jungtinių Tautų neiggaliụjų teisių konvenciją, kuria ịsipareigojo užtikrinti visų asmenų, turinčių negalią, visapusišką dalyvavimą visuomeniniame gyvenime. Šių asmenų ịtraukties ị bendruomenę svarba akcentuojama ir Lietuvos pažangos strategijoje „Lietuva 2030“, kurioje pabrèžiamas esminių pokyčių poreikis šioje srityje.

Teisiniai dokumentai reglamentuoja paslaugų prieinamumą asmenims, turintiems psichosocialinę negalią, tačiau realybèje socialinès atskirties problemos išlieka. A. Roszmann'as ir kt. (2014) atliko tyrimą ir nustate, kad patenkinama dauguma globos institucijų gyventojų fizinių ir medicininių poreikių, tačiau mažai dèmesio skiriama psichologiniams ir socialiniams poreikiams. Paslaugų asmenims, turintiems negalią, teikimas suprantamas nebe kaip vienpusis organizacijos procesas, asmenis, turinčius negalią, integruojant ị bendruomenę, vis didesnị vaidmeni vaidina paslaugų gavėjai ir kiti visuomenès nariai (Heiman, 2017). 2014 metais Lietuvoje pradètas globos pertvarkos procesas, kuriuo siekiama paslaugas ir reikiamą pagalbą organizuoti ir teikti bendruomeneje, atsižvelgiant ị individualius asmens, turinčio negalią, poreikius.

Lietuvoje gyvena daugiau kaip 248 tūkst. asmenų, turinčių negalią, tai beveik 10 proc. visų šalies gyventojų (SADM, 2020). Negalią turintiems asmenims reikia ìvairios pagalbos ir socialinių paslaugų, kurių organizavimas turètų būti nuolat tobulinamas bei plečiamas. Nors psichosocialinę negalią turinčių asmenų dalyvavimas bendruomenès gyvenime plačiai aptariamas mokslo diskurse, socialinių paslaugų prieinamumo galimybės bendruomenèje Lietuvos regionuose vis dar neištirtos. Stokojama tyrimų, kurie leistų nustatyti socialinių paslaugų prieinamumo galimybes, atsižvelgiant ị asmens, turinčio psichosocialinę negalią, individualius poreikius.

Lietuvoje žmonių, turinčių negalią, pagalbos procesus administruoja ịvairios nacionalinio ir vietinio lygmens institucijos. Paslaugų plètra vykdoma neturint patikimų duomenų ir yra nepakankama, socialinès ir užimtumo paslaugos pla- 
nuojamos ir teikiamos kompleksiškai, neįvertinus individualių poreikių, nedaug nedirbančių asmenų ịsitraukia ị užimtumo rẻmimo sistemą, pasiūlymai ịsidarbinti neatitinka asmenų ir darbdavių poreikių, darbo rinka nemotyvuota ịdarbinti asmenų, turinčių negalią (Valstybinio audito ataskaita, 2020).

Straipsnyje analizuojamos psichosocialinę negalią turinčių asmenų socialinių paslaugu prieinamumo galimybės bendruomeneje, remiantis atvejo analize vienoje Lietuvos savivaldybèje. Tyrimas nukreiptas ị pagalbos priemonių bei sprendimų paiešką, siekiant užtikrinti psichosocialinę negalią turinčių asmenų visapusišką funkcionavimą visuomeniniame gyvenime. Tyrimo uždaviniai: 1) išsiaiškinti institucinès pagalbos galimybes asmenims, turintiems psichosocialinę negalią; 2) identifikuoti problemas, kurių kyla teikiant socialines paslaugas asmenims, turintiems psichosocialinę negalią, bendruomenèje; 3) išanalizuoti asmenų, turinčių psichosocialinę negalią, įsidarbinimo galimybes.

Straipsnio tikslas: remiantis atvejo analize atskleisti psichosocialinę negalią turinčių asmenų socialinių paslaugų prieinamumo galimybes bendruomenèje.

Straipsni sudaro keturios dalys: pirmoje dalyje pateikiama socialinių paslaugų prieinamumo asmenims, turintiems psichosocialinę negalią, teorija; antroje dalyje pristatoma šių asmenų socialinès ịtraukties problematika; trečioje dalyje pristatoma empirinio tyrimo metodologija ir pateikiama tyrimo rezultatų analizè, straipsnio pabaigoje pateikiamas tyrimo apibendrinimas ir formuluojamos išvados.

\section{Socialinių paslaugų prieinamumas asmenims, turintiems psichosocialinę negalią}

Siekiant, kad asmenys, turintys negalią, sėkmingai funkcionuotų bendruomenèje, svarbu užtikrinti ịvairių socialinių paslaugų teikimą. Socialinių paslaugų samprata ir tikslai nukreipti ị pagalbos asmeniui (šeimai) procesus. T. Heiman (2017) socialines paslaugas apibūdina kaip stacionarias, slaugos, bendruomenines, pagalbos namuose ar renginiuose ir kitas ị pagalbą bei paramą orientuotas paslaugas.

Valstybė, siekdama užtikrinti socialinių paslaugų teikimą asmenims, turintiems negalią, reglamentuoja jų planavimą, organizavimą, formavimą, rūšis ir finansavimą. Socialinių paslaugų įstatyme (2006) pažymima, kad socialinių paslaugų valdymas apima socialinių paslaugų planavimą, organizavimą, kompetencijos pasiskirstymą, socialinių paslaugų kokybès vertinimą, priežiūrą ir kontrolę valstybès bei vietos savivaldos lygmenimis. Socialinès paslaugos gali būti teikiamos tiek socialinių paslaugų įstaigose (socialinès globos namuose, šeimynose, laikino gyvenimo namuose, dienos socialinès globos centruose, savarankiško gyvenimo namuose, socialinès priežiūros centruose, bendruomeninèse ịstaigose ir kt.), tiek asmens namuose (SADM, 2019). Bendrosios ir specialiosios socialinės paslaugos 
psichosocialinę negalią turintiems asmenims teikiamos visose 60-yje Lietuvos savivaldybių.

Lietuvoje nuo 2018 metų pradèta teikti asmeninio asistento paslauga. Remiantis LR socialinès apsaugos ir darbo ministro ịsakymu Nr. A1-83 (2018), asmeninio asistento paslauga - namų ir viešojoje aplinkoje (palydint ir komunikuojant) individualiai asmeniui teikiama pagalba, padedanti ịgalinti asmenị būti savarankišką ir užtikrinanti svarbiausias jo gyvybinès veiklos funkcijas. Ši paslauga suprantama kaip individualizuotos bendruomeninès paslaugos asmenims, turintiems negalią. Paslauga gali būti skiriama dèl psichosocialinès negalios, kuri visiškai arba vidutiniškai riboja žmonių veiklą, galimybę orientuotis, judèti, dirbti ir savarankiškai tvarkyti asmeninį bei socialinị gyvenimą.

Socialinès paslaugos psichosocialinę negalią turintiems asmenims finansuojamos, remiantis LR Vyriausybès nutarimu Nr. 978 (2006) iš savivaldybès ir Lietuvos Respublikos valstybės biudžetų lěšų. Psichosocialinę negalią turintiems asmenims pagalba teikiama ir finansuojant socialinès reabilitacijos paslaugų neịgaliesiems bendruomenejje projektus (Drake ir kt., 2016). Projektinis finansavimas leidžia didinti socialinès ịtraukties procesus bendruomeneje ir ugdyti asmenų, kuriems nustatyta psichosocialinè negalia, savarankiškumą. R. E. Drake'as ir kt. (2016) pažymi, kad asmeninio asistento pagalbą žmonèms, turintiems negalią, dažniausia teikia nevyriausybinio sektoriaus organizacijos.

Socialinių paslaugų teikimą reglamentuoja ịstatymai, teisès aktai, kiti norminiai dokumentai, numatantys paslaugų planavimą, organizavimą ir formavimą, jų rūšis ir finansavimą. Pagalbos procesuose svarbu formuoti bendruomenès, visuomenès požiūrị, ịsitraukti ị pagalbos procesus asmenims, kurie negali savimi pasirūpinti dèl psichosocialinių ar fizinių apribojimų.

\section{Socialinės ịtraukties problemos, kylančios asmenims, turintiems psichoso- cialinę negalią}

Socialinès įtraukties procesai visuomenèje atskleidžia valstybės brandą, jos gebèjimą pasirūpinti labiausiai pažeidžiamomis gyventojų grupèmis. S. C. Simplica ir kt. (2015) mano, kad socialinė įtrauktis yra svarbus intelekto ir raidos negalią turinčių žmonių, šeimų, paslaugų teikejjų ir politikos formuotojų tikslas. Ypač aktualus lygiateisiškumo principas, kai planuojant visuomenès gyvenimą vienodai atsižvelgiama ị kiekvieno žmogaus poreikius, o ištekliai naudojami taip, kad kiekvienam asmeniui būtų garantuotos lygios galimybẻs. Psichosocialinę negalią turintys asmenys yra visuomenès nariai ir turi teisę likti savo bendruomenejje, kur jiems turi būti teikiama visokeriopa švietimo, mokymo, sveikatos apsaugos, įdarbinimo ir socialinių paslaugų struktūrų pagalba. 
T. Hall ir kt. (2019) teigimu, socialinè įtrauktis yra žmogaus teisè, suteikta visiems, įskaitant psichikos ligomis sergančius asmenis. B. Holzner'is (2016) teigia, kad įtrauktis - tai visuomenès kūrimosi procesas, kuriame visos socialinès grupès dalijasi socialine, ekonomine ir kultūrine patirtimi. S. R. Copeland ir kt. (2014) teigimu, socialinè įtrauktis psichosocialinę negalią turintiems asmenims yra problemiška, nes skirtingo intelekto ir raidos sutrikimų turintys žmonès socialinę adaptaciją išgyvena skirtingai. Pavyzdžiui, žmonėms, turintiems lengvą ir sunkią psichosocialinę negalią, labiausiai gresia socialinè izoliacija ir atskirtis, tuo tarpu žmonès, turintys vidutinę psichosocialinę negalią, mėgsta užmegzti artimas draugystes su kitais asmenimis.

Psichosocialinę negalią turinčių asmenų socialinė integracija yra viena svarbiausių aktualijų tiek Lietuvos, tiek ir Europos šalių sveikatos bei socialinès apsaugos srityse. Mokslininkai mano, kad socialinès ịtraukties problematika aktuali daugelyje šalių (Ranerupa, Henriksenb, 2019; Rogers, 2021).

T. Heiman (2017) nustaté, kad siekiant asmenų, turinčių negalią, ịtraukties ị bendruomenę svarbus bendradarbiavimo poreikis. Negalios ir įtraukties paradigmos atejusios iš labiau išsivysčiusių šalių, kuriose siekiama tenkinti individualius žmonių, turinčių negalią, poreikius, puoselèti lygybès, bendruomenès solidarumą (Swanwick ir kt., 2020). Gyvenimas bendruomenèje psichosocialinę negalią turintiems žmonèms sudaro galimybę gyventi savarankišką gyvenimą ir jaustis pilnaverčiu visuomenès nariu.

Žmogaus, turinčio negalią, sėkmingas funkcionavimas priklauso nuo komplekso veiksnių, vienas kurių yra dalyvavimas darbo rinkos procesuose. Darbas naudingas tiek žmogaus sveikatai, tiek jo asmeninei gerovei (Dwyer ir kt., 2019). Siekiant sèkmingo neịgaliųjų dalyvavimo darbo rinkoje, svarbu didinti užimtumą ir taip ugdyti savarankiško gyvenimo ịgūdžius (Gray ir kt., 2014).

Lietuvoje asmenų, turinčių negalią, integracija ị darbo rinką - didelė problema, tuo tarpu darbas žmogui yra jo sėkmingo funkcionavimo visuomenèje pagrindas. Statistikos duomenimis, 2019 m. Lietuvoje buvo 13 procentų (26 iš 207) asmenų, kuriems Neigalumo ir darbingumo nustatymo tarnyba teikè rekomendacijas dèl pagalbos poreikio ir savivaldybèse gavo specialiąsias paslaugas (Valstybinio audito ataskaita, 2020).

Tyrimai atskleide, jeigu asmuo, turintis psichosocialinę negalią, ir dalyvauja darbo rinkoje, jis yra marginalizuojamas, tai lemia užimtumo tvarumą ir karjeros plètrą (Hardonk, Halldórsdóttir, 2021). Svarbu formuoti teigiamą visuomenès požiūrị ị asmenis, turinčius psichosocialinę negalią. Užsienio šalių patirtis atskleidè, kad daugẻja socialiai atsakingų ịmonių, kurios įdarbina asmenis, turinčius negalią, ir taip prisideda prie socialinès įtraukties plètros darbo rinkoje, tai netgi tampa organizacijų strateginio planavimo dalimi (Miethlich, Oldenburg, 2019). Kita vertus, 
kalbėjimas apie teisę ị darbą skamba beprasmiškai, jeigu darbo vieta nepritaikyta asmeniui, turinčiam negalią, pvz., kurtieji ar neprigirdintieji, aklieji, žmonès, kurių silpnas regejjimas, ar turintieji kognityvinių funkcijų sutrikimą negali naudotis darbo vietoje ịdiegtomis technologijomis (Blanck, 2020). M. De Picker (2020) nuomone, reikètų orientuotis ị organizuotos pagalbos teikimą, didesnị prieinamumą ir individualius poreikius bei aplinkos pritaikymą. Darbo rinkos procese ypač svarbi asmeninė pagalba asmenims, turintiems psichosocialinę negalią.

Lietuvoje $2016 \mathrm{~m}$. prasidèjo institucinès globos pertvarkos procesai, siekiant užtikrinti paslaugų asmenims, turintiems negalią, teikimą bendruomenėje. Apklausti Lietuvos gyventojai ir institucinès globos pertvarkos dalyviai. Tyrimas atskleidè, kad institucinès globos pertvarkai pritaria 60 proc. asmenų. 89 proc. apklaustujų mano, kad psichosocialinę negalią turintys žmonès visuomenèje diskriminuojami. 47 proc. asmenų nenorètų dirbti ar mokytis kartu su žmonėmis, turinčiais psichosocialinę negalią. 53 proc. pažymejjo, kad sunkią psichosocialinę negalią turinčiais žmonèmis privalo rūpintis valstybè (Socialinis pranešimas, 2016-2017).

Itraukios visuomenès pagrindas yra socialinių ryšių tinklo kūrimas ir jo plètojimas (Zhao, Zhang, 2018). Reikia pažymèti, kad žmonių, turinčių negalią, socialinė atskirtis išlieka neišspręsta pasauliniu lygmeniu ir tai kelia iššūkių, siekiant užtikrinti žmogaus teises (Hall ir kt., 2019). Tyrimai atskleidè, kad negalia ir įtrauktis priklauso nuo politikų, visuomenès požiūrio, bendruomenès ryšių (Swanwick ir kt., 2020).

Psichosocialinę negalią turintys asmenys yra labiau pažeidžiami, jie dažniau serga, patiria socialinę atskirtį, susiduria su nedarbo ir skurdo problemomis. Psichosocialinę negalią turinčių asmenų socialinė integracija - viena svarbiausių tiek Lietuvos, tiek ir Europos šalių sveikatos ir socialinès apsaugos aktualijų. Manoma, kad nuo valstybės socialinès politikos formuotojų požiūrio ir finansinių išteklių priklauso socialinių paslaugų prieinamumas asmenims, turintiems negalią. Vis dèlto ne mažiau svarbus ir pačios visuomenès indẻlis, požiūris ị žmones, turinčius psichosocialinę negalią. Būtini ir instituciniai pokyčiai, siekiant didinti paslaugų prieinamumą, tenkinant šių asmenų individualius poreikius.

\section{Tyrimo metodologija}

Siekiant ištirti psichosocialinę negalią turinčių asmenų integracijos ị bendruomenę galimybes, pasirinkta atlikti kokybini tyrimą Anykščių rajone, kuriuo siekta suprasti subjektyvias tyrimo dalyvių patirtis ir jas įvertinti. Tyrimo rezultatai siejami su tyrimo vietos - Anykščiu rajono socialinėmis sąlygomis. Tyrimo tikslas empiriškai pagrįsti psichosocialinę negalią turinčių asmenų integracijos ị bendruomenę galimybes Anykščių rajone. 
Kokybinis tyrimas atliktas struktūruoto interviu metodu, apklausiant ekspertus. Ekspertiniam tyrimui atlikti parengtas tyrimo klausimynas. Ekspertų apklausa vykdyta tiesioginio interviu metu. Tyrimo duomenys analizuoti turinio analizès (angl. Content) metodu. Taikant struktūruotą interviu metodą klausimai ir visa procedūra numatyti iš anksto, tad interviu procese mažai kas keista.

Vykdant dalyvių atranką, siekta, kad jų patirtis būtų kuo įvairesnè, siekiant kuo įvairiapusiškiau atskleisti tyrimo objektą - taip, kaip jị supranta tyrimo dalyviai. Skirtingas objekto supratimas leidžia jị pamatyti iš skirtingų perspektyvų ir skirtingų jo pusių.

Tiriamieji - septyni Anykščiu rajono savivaldybès teritorijoje socialines paslaugas psichosocialinę negalią turintiems asmenims teikiančių institucijų atstovai - ekspertai, pagal savo turimas kompetencijas geriausiai susipažinę su tiriamos temos ypatumais ir galintys tiksliausiai atsakyti ị užduotus tyrimo klausimus. Informantų atrankos kriterijai: išsilavinimas - aukštasis, darbo stažas - ne mažiau kaip penkerių metų darbo patirtis įstaigoje, teikiančioje paslaugas psichikos negalią turintiems asmenims, dalyvavimas integracijos i bendruomenę programose. Informantų charakteristikos pateiktos 1 lentelèje.

1 lentele. Informantų charakteristikos

\begin{tabular}{|l|l|l|l|}
\hline $\begin{array}{l}\text { Informanto vardas } \\
\text { (pakeistas) }\end{array}$ & Amžius & $\begin{array}{l}\text { Darbo } \\
\text { stažas }\end{array}$ & Institucijos tipas \\
\hline Astra & 50 & 6 & $\begin{array}{l}\text { Trumpalaikes socialines paslaugas psichi- } \\
\text { kos negalią turintiems asmenims teikianti } \\
\text { biudžetinę istaiga }\end{array}$ \\
\hline Paulinta & 50 & 13 & $\begin{array}{l}\text { Trumpalaikes socialines paslaugas psichi- } \\
\text { kos negalią turintiems asmenims teikianti } \\
\text { biudzzetine istaiga }\end{array}$ \\
\hline Julija & 48 & 7 & $\begin{array}{l}\text { Ilgalaikes socialines paslaugas psichikos } \\
\text { negalią turintiems asmenims teikianti biu- } \\
\text { džetinè istaiga }\end{array}$ \\
\hline Vilija & 54 & 8 & $\begin{array}{l}\text { Trumpalaikes socialines paslaugas psichi- } \\
\text { kos negalią turintiems asmenims teikianti } \\
\text { biudžetinè istaiga }\end{array}$ \\
\hline Živilé & 46 & 14 & $\begin{array}{l}\text { Sveikatos priežiūros paslaugas psichikos } \\
\text { negalią turintiems asmenims teikianti viešoji } \\
\text { istaiga }\end{array}$ \\
\hline Daina & 56 & 16 & $\begin{array}{l}\text { Ilgalaikes socialines paslaugas psichikos } \\
\text { negalią turintiems asmenims teikianti valsty- } \\
\text { binè istaiga }\end{array}$ \\
\hline Ramuné & 51 & 11 & $\begin{array}{l}\text { Ilgalaikes socialines paslaugas psichikos } \\
\text { negalią turintiems asmenims teikianti valsty- } \\
\text { binę istaiga }\end{array}$ \\
\hline
\end{tabular}


Ekspertų apklausa tiesioginio interviu metu vykdyta vadovaujantis savanoriškumo, privatumo, konfidencialumo, anonimiškumo ir pagarbos asmeniui etikos principais. Tyrimo ribotumas: straipsnyje aptariamos tik vienoje savivaldybeje paslaugas psichosocialinę negalią turintiems asmenims teikiančių institucijų patirtys.

\section{Empirinio tyrimo rezultatai}

Informantų nuomonès atliekant tyrimą išskaidytos semantiniais vienetais ir sugrupuotos ị kategorijas bei subkategorijas. Pagrindinis tyrimo tikslas - teoriškai ir empiriškai išsiaiškinti psichosocialinę negalią turinčių asmenų socialinių paslaugų prieinamumo bendruomenèje galimybes. Atliekant tyrimą buvo svarbu sužinoti tyrimo dalyvių nuomonę apie socialinès įtraukties galimybes bendruomenèje asmenims, turintiems psichosocialinę negalią (žr. 2 lentelę).

Informantai mano, kad asmenims, turintiems negalią, teikiama pagalba, paslaugų prieinamumas, tinkama paslaugų infrastruktūra skatina socialinès įtraukties procesus. Asmens, turinčio psichosocialinę negalią, dalyvavimas visuomeniniame gyvenime priklauso nuo paslaugų prieinamumo. Socialinės paslaugos yra tarsi sèkmingo funkcionavimo bendruomeneje pamatas. Tyrimu nustatyta, kad pagalba teikiama, tačiau esminè ịtraukties problema išlieka - ne visi bendruomenès nariai turi vienodas galimybes gauti pagalbą.

Tyrimas atskleidè, kad asmenų, turinčių psichosocialinę negalią, dalyvavimas darbo rinkos procesuose yra sudėtingas, jų integracija ị darbo rinką informantų ívardyta kaip aktuali tema, tačiau valstybiniu lygmeniu tam skiriama nepakankamai dèmesio. Tyrimas atskleidè, kad asmenims, turintiems psichosocialinę negalią, ịsidarbinti beveik neịmanoma, tad susidaro sąlygos plisti skurdui, nepritekliui ir atskirčiai. Problemų kyla ne vien asmenims, turintiems negalią, dažnai ị ,,skurdo pinkles“" patenka ir asmenị su negalia slaugantys šeimos nariai.

Tyrime dalyvavę ekspertai teigiamai vertina psichosocialinę negalią turinčių asmenų galimybes Anykščių rajone dalyvauti bendruomeniniame gyvenime. Be to, informantai nurodo tobulintinas sritis, siekiant užtikrinti sėkmingą ịtraukti i bendruomenę, plètojant institucinei globai alternatyvias bendruomenines socialines paslaugas: „Psichikos negalią turinčių asmenų integracija ị bendruomenę Anykščių rajone yra galima, neigaliụų integraciją vertinu teigiamai, nes integracija pagerina neigaliojo gyvenimo kokybę“"(Julija). Svarbu pažymėti, kad paslaugų plètojimas ir jų teikimo prieinamumo didinimas neatsiejamas nuo individualių asmens poreikių, tad ypač svarbu palaikyti ryšį ne tik instituciniu, bet ir asmeniniu lygmeniu. 
Odeta Merfeldaitė, Gintarè Sabaliauskienė, Laura Gardziulevičienė

2 lentelè. Psichosocialinę negalią turinčių asmenų socialinės įtraukties galimybès bendruomenèje

\begin{tabular}{|c|c|c|}
\hline Kategorija & Subkategorijos & Patvirtinantys teiginiai \\
\hline \multirow{11}{*}{$\begin{array}{l}\text { Psichikos nega- } \\
\text { lią turinčių as- } \\
\text { menų galimy- } \\
\text { bės integruotis } \\
\text { ì bendruomenę }\end{array}$} & \multirow[t]{2}{*}{$\begin{array}{l}\text { Paslaugų prieinamumo } \\
\text { užtikrinimas }\end{array}$} & $\begin{array}{l}\text { „...plètojamas paslaugų neigaliesiems priei- } \\
\text { namumas, didinamas neịgaliujų savarankiš- } \\
\text { kumas“ (Julija) }\end{array}$ \\
\hline & & $\begin{array}{l}\text { „...jiems (...) teikiama visokeriopa švietimo, } \\
\text { mokymo, sveikatos apsaugos, ịdarbinimo } \\
\text { ir socialinių paslaugų struktūrų pagalba. } \\
\text { Esminis neịgaliujų integracijos programos } \\
\text { principas ir uždavinys - galimybių suvieno- } \\
\text { dinimas“ (Vilija) }\end{array}$ \\
\hline & $\begin{array}{l}\text { NVO sektoriaus vai- } \\
\text { dmens didinimas }\end{array}$ & $\begin{array}{l}\text { „....stiprinamas nevyriausybinio sektoriaus } \\
\text { vaidmuo, kas padidina integracijos ị ben- } \\
\text { druomenę galimybes“ (Julija) }\end{array}$ \\
\hline & \multirow[t]{7}{*}{ Integracija ị darbo rinką } & $\begin{array}{l}\text { „...labai silpnai arba visai nėra išvystyta ịsi- } \\
\text { darbinimo galimybės asmenims su psichine } \\
\text { negalia“ (Paulinta) }\end{array}$ \\
\hline & & $\begin{array}{l}\text { „Asmenys su psichikos negalia (...) neturi } \\
\text { didelių įsidarbinimo galimybių“(Živilè) }\end{array}$ \\
\hline & & „,... insidarbinimo jiems negarantuoja“ (Vilija) \\
\hline & & $\begin{array}{l}\text { „...neigaliujų integracijai i darbo rinką } \\
\text { trukdo tiek objektyvios, tiek ir subjektyvios } \\
\text { darbo užimtumo problemos“ (Paulinta) }\end{array}$ \\
\hline & & $\begin{array}{l}\text { „Praktiškai psichikos negalią turintis asmuo } \\
\text { issidarbinti galimybių neturi, nes dauguma } \\
\text { neturi reikiamo išsilavinimo arba, jei ir } \\
\text { turi, tai renkasi gauti išmokas, o ne dirbti“ } \\
\text { (Ramunè) }\end{array}$ \\
\hline & & $\begin{array}{l}\text { „....jei psichinė negalia yra lengva ir žmogus } \\
\text { yra savarankiškas, o užimtumo tarnyboje } \\
\text { yra vykdomos programos, skatinančios } \\
\text { neigaliujų integraciją i darbo rinką, tokiu } \\
\text { atveju galimybė integruotis į darbo rinką } \\
\text { yra“(Julija) }\end{array}$ \\
\hline & & $\begin{array}{l}\text { „....menkos globos namų gyventojų ịsidarbi- } \\
\text { nimo galimybės“ (Živilè) }\end{array}$ \\
\hline & $\begin{array}{l}\text { Visuomenès nuostatų } \\
\text { kaita }\end{array}$ & $\begin{array}{l}\text { „Anykščių rajono psichikos negalią turinčių } \\
\text { asmenų integracijai į bendruomenę reikia } \\
\text { sudaryti sąlygas pasijusti pilnaverčiais jos } \\
\text { nariais“ (Vilija) }\end{array}$ \\
\hline
\end{tabular}

Psichosocialinę negalią turinčių asmenų ir socialinės įtraukties proceso suinteresuotų dalyvių (gyventojų, specialistų, psichikos negalią turinčių asmenų ir jų ar- 
timujjų) nuostatos ị socialinès įtraukties procesus nevienodai išreikštos, tačiau palankus priemonių vertinimas atskleidžia asmenų, turinčių psichosocialinę negalią, socialinès ịtraukties galimybes. Vienas iš respondentų patvirtino, kad „palankus integracijos priemonių vertinimas atskleidžia palankias psichikos neiggaliujjų integracijos ị bendruomenę [galimybes]“" (Ramunè). Kita vertus, svarbus ir šeimos, kurioje gyvena asmuo, turintis negalią, požiūris, motyvacija dalyvauti bendruomenès gyvenime. Mažinant asmenų, turinčių psichosocialinę negalią, socialinę atskirtị, būtina bendradarbiauti visais lygmenimis.

Kaip svarbų veiksnị ar priemonę, padedančią psichosocialinę negalią turintiems asmenims integruotis ị bendruomenę, informantai nurodè tarpinstitucinị bendradarbiavimą. Atliekant tyrimą siekta išsiaiškinti tarpinstitucinio bendradarbiavimo svarbą (žr. 3 lentelę).

3 lentele. Tarpinstitucinio bendradarbiavimo svarba

\begin{tabular}{|c|c|c|}
\hline Kategorija & Subkategorijos & Patvirtinantys teiginiai \\
\hline \multirow[t]{5}{*}{$\begin{array}{l}\text { Tarpinstitucinio } \\
\text { bendradarbiavi- } \\
\text { mo svarba }\end{array}$} & \multirow[t]{3}{*}{$\begin{array}{l}\text { Svarba neiga- } \\
\text { liesiems }\end{array}$} & $\begin{array}{l}\text { „Yra labai svarbus tarpinstitucinis bendradarbiavi- } \\
\text { mas, nes tik dirbant komandoje psichikos negalią } \\
\text { turintys asmenys gali gauti reikalingą pagalbą } \\
\text { švietimo, sveikatos, socialinės apsaugos, užimtumo } \\
\text { ir kt. srityse“ (Daina) }\end{array}$ \\
\hline & & $\begin{array}{l}\text { „Labai svarbus tarpinstitucinis bendradarbiavimas } \\
\text { teikiant paslaugas psichikos negalią turintiems } \\
\text { asmenims. Seniūnijos, kaimo bendruomenės yra } \\
\text { vieni pagrindinių partnerių, padedančių ar bent jau } \\
\text { turinčių padėti integruotis asmenims į bendruome- } \\
\text { nę. Seniūnijose, kaimo bendruomenèse vykstantys } \\
\text { renginiai turi burti ir yra skirti visiems bendruome- } \\
\text { nės nariams“ (Živilè) }\end{array}$ \\
\hline & & $\begin{array}{l}\text { „Efektyviam socialinių paslaugų tekimui ypatin- } \\
\text { gai svarbus tarpinstitucinis bendradarbiavimas, } \\
\text { leidžiantis tikslingai ir kryptingai organizuoti, teikti } \\
\text { ir koordinuoti kompleksinę pagalbą ịvairioms soci- } \\
\text { alinių paslaugų gavèjų grupėms“ (Vilija) }\end{array}$ \\
\hline & \multirow[t]{2}{*}{$\begin{array}{l}\text { Svarba pagalbą } \\
\text { teikiančioms } \\
\text { institucijoms }\end{array}$} & $\begin{array}{l}\text { „Tarpinstitucinis bendradarbiavimas yra labai svar- } \\
\text { bus ir neišvengiamas, nes viena socialinės globos } \\
\text { įstaiga negalètų funkcionuoti ir teikti paslaugų“ } \\
\text { (Julija) }\end{array}$ \\
\hline & & $\begin{array}{l}\text { „Labai svarbus [tarpinstitucinis bendradarbiavi- } \\
\text { mas], būtina stiprinti institucijų pastangas kelti } \\
\text { Anykščių rajono ir visos Lietuvos gyventojų sąmo- } \\
\text { ninguma“" (Ramunė) }\end{array}$ \\
\hline
\end{tabular}


Remiantis informantų nuomone, tarpinstitucinis bendradarbiavimas svarbus ir patiems negalią turintiems asmenims, ir pagalbą jiems teikiančioms institucijoms: bendradarbiaujant geriau tenkinami žmonių poreikiai, įtraukiama bendruomenè, pritraukiama daugiau išteklių. Informantai atkreipia dèmesị ir ị nevyriausybines organizacijas: „Šiuo aspektu reikètų išnaudoti nevyriausybinių organizacijų potencialą ir didinti visuomenès švietimą“ (Ramunė); ,...sudaromos bendradarbiavimo sutartys su kitomis institucijomis - NVO, kultūros, švietimo ir kitomis įstaigomis, sutariant kartu dalyvauti projektinėse veiklose, pritraukiant finansavimą; sociokultūrinèse veiklose, švietimo ir kitose veiklose, organizuojant užimtumą, aprūpinimą, skatinant integraciją ị bendruomenę ir pan."(Julija).

Ekspertų apklausa atskleide, kad psichosocialinę negalią turintiems asmenims ịvairiose srityse dèl negalios kyla daugybè kliūčių. Problemos, kurių kyla integruojant psichosocialinę negalią turinčius asmenis ị bendruomenę, susijusios su socialinès atskirties problematika, neigiamomis visuomenès nuostatomis dèl psichosocialinę negalią turinčių asmenų, pačių asmenų, turinčių negalią, nepasirengimu dalyvauti bendruomenès veiklose ir nepakankamai išplètota Anykščių rajono socialine infrastruktūra.

\section{Išvados}

Psichosocialinę negalią turintiems asmenims ịvairiose srityse kyla daugybè kliūčių. Problemos, kurių kyla psichosocialinę negalią turinčius asmenis integruojant ị bendruomenę, susijusios su socialine atskirtimi, neigiamomis visuomenés nuostatomis, nepakankamai išplètota socialine infrastruktūra ir pačių asmenų, turinčių negalią, nepasirengimu dalyvauti visuomeniniame gyvenime.

Atvejo analizè atskleidè, kad bendruomenès požiūris ị psichosocialinę negalią turinčius asmenis yra iššūkis, siekiant sèkmingos socialinès įtraukties bendruomenejje. Nuolatiniai palankūs santykiai su socialine aplinka teigiamai veikia asmens, turinčio negalią, sveikatą ir gerovę. Atlikus tyrimą nustatyta, kad visuomenė netolerantiška asmenims, turintiems psichosocialinę negalią, tai ypač apsunkina socialinès ịtraukties procesus.

Atlikus tyrimą paaiškejjo, kad paslaugų prieinamumas neišplètotas ir ne visada atitinka žmonių, turinčių negalią, poreikius. Paslaugų organizavimas ir teikimas, orientuojantis ị individualios pagalbos teikimą, padètų asmenims, turintiems psichosocialinę negalią, îveikti kliūtis, ugdytis socialinius ịgūdžius ir galbūt dalyvauti darbo rinkos procesuose. Šie asmenys darbo rinkai neparengti ir nepasiruošę, tam reikia įdirbio tiek ugdant bendruomenès tolerantiškumą, tiek asmens, turinčių negalią, savarankiškumą. 
Tyrimas atskleidè, kad socialinès ịtraukties procese svarbus veiksnys yra tarpinstitucinis bendradarbiavimas, nes i pagalbos teikimo procesus itraukiama ir bendruomenè, tenkinami asmenų, turinčių negalią, poreikiai, pritraukiama daugiau išteklių. Akivaizdu, kuo daugiau suinteresuotų grupių itraukiama i pagalbos teikimo procesą, tuo labiau plètojama socialinès įtraukties idèja, formuojamas teigiamas bendruomenès požiūris ị asmenį, turintị psichosocialinę negalią.

\section{Literatūra}

Blanck, P. (2020). Disability Inclusive Employment and the Accommodation Principle: Emerging Issues in Research, Policy, and Law. Journal of Occupational Rehabilitation, Vol. 7(30), p. 505-510. Prieiga internete: https://doi.org/10.1007/s10926-020-09940-9.

Copeland, S. R., Luckasson, R., Shauger, R. (2014). Eliciting perceptions of satisfaction with services and supports from persons with intellectual disability and developmental disabilities: A review of the literature. Journal of Intellectual Disability Research, Vol. 58(12), p. 1141-1155. Doi: 10.1111/jir.12114.

De Picker, M. (2020). Rethinking inclusion and disability activism at academic conferences: strategies proposed by a PhD student with a physical disability. Disability \& Society, Vol. 35(1), p. 163-167. Doi: 10.1080/09687599.2019.1619234.

Drake, R. ir kt. (2016). Individual Placement And Support Services Boost Employment For People With Serious Mental Illnesses, But Funding Is Lacking. Health Affairs. Behavioral Health, Vol. 35(6), p. 1098-105. Doi: $10.1377 /$ hlthaff. 2016.0001 .

Dwyer, P., Scullion, L., Jones, K., McNeill, J., Stewart, A. B. R. (2019). Work, welfare, and wellbeing: The impacts of welfare conditionality on people with mental health impairments in the UK. Social Policy \& Administration, Vol. 54(2), p. 311-326. Doi: 10.1111/spol.12560.

European Commission document, COM. (2021). 101 final. Briuselis, 202103 03. Communication from the Commission to the European Parliament, the Council, the European Economic and Social Committee and the Committee of the Regions. Equality Union. 2021-2030 m. Disability Rights Strategy. Prieiga internete: https://eur-lex.europa.eu/legal-content/LT/TXT/?uri=COM:2021:101:FIN\#PP4Contents.

Gray, K. M. ir kt. (2014). Outcomes in young adulthood: Are we achieving community participation and inclusion? Journal of Intellectual Disability Research, Vol. 58(8), p. 734-745.

Hall, T., Kakuma, R., Palmer, L., Minas, H., Martins, J. and Kermode, M. (2019). Social inclusion and exclusion of people with mental illness in Timor-Leste: a qualitative investigation with multiple stakeholders. BMC Public Health, Vol. 19 (702), p. 1-13. Prieiga internete: https://doi.org/10.1186/s12889-019-7042-4.

Hardonk, S., Halldórsdóttir, S. (2021). Work Inclusion through Supported Employment? Perspectives of Job Counsellors in Iceland. Scandinavian Journal of Disability Research, Vol. 23(1), p. 39-49. Doi: https://doi.org/10.16993/sjdr.767.

Heiman, T. (2017). Children with Special Needs: The Role of the Family. The Open University of Israel.

Holzner, B. (2016). The Concept "Integration" in Sociological Theory. The Sociological Quarterly, Vol. 8, p. 5162. Doi: doi.org/10.1111/j.1533-8525.1967.tb02273.x.

Lietuvos pažangos strategija „Lietuva 2030“. (2012). Valstybès žinios, 2012-05-30, Nr. 61-3050.

Lietuvos Respublikos socialinès apsaugos ir darbo ministerija. (2020). Neigalumo statistika ir dinamika. Prieiga internete: https://socmin.lrv.lt/lt/veiklos-sritys/socialine-integracija/neigaliuju-socialine-integracija/ statistika-2.

Lietuvos Respublikos Socialiniu paslaugu ịstatymas. (2006). 2006 m. sausio 19 d., Nr. X-493.

LR socialinès apsaugos ir darbo ministro įsakymas Nr. A1-83 „Dèl asmeninio asistento paslaugų organizavimo ir teikimo bei asmeninio asistento veiklos gairių patvirtinimo“. (2018). TAR, 2018-03-05, Nr. 3526.

Miethlich, B., Oldenburg, A. G. (2019). How Social Inclusion Promotes Sales: An Analysis of the Example of Employing People with Disabilities. Journal of Marketing Research and Case Studies, Vol. 2019, article ID 463316, p. 1-15. Doi: 10.5171/2019.463316. 
Odeta Merfeldaitė, Gintarè Sabaliauskienė, Laura Gardziulevičienė

O'Donovan, M. A. (2021). The Elusive Inclusive University: What Does This Look Like for Students With Intellectual Disability? An Irish Perspective. Journal of Policy and Practice in Intellectual Disabilities, Vol. 18, No. 1, p. 68-74. Doi: 10.1111/jppi.12375.

Ranerupa, A., Henriksenb, H. Z. (2019). Value positions viewed through the lens of automated decision-making: The case of social services. Government Information Quarterly, Vol. 36, 101377, p. 1-13. Doi: https://doi. org/10.1016/j.giq.2019.05.004.

Rogers, M. (2021). Federalism and the welfare state in Latin America. Regional \& Federal Studies, Vol. 31(1), p. 163-184. Doi: 10.1080/13597566.2020.1749841.

Roszmann, A. ir kt. (2014). Needs assessment of long term care institutions residents with dementia. Acta Neuropsychologica, Vol. 12 (1), p. 65-72.

Simplica, S. C. ir kt. (2015). Defining social inclusion of people with intellectual and developmental disabilities: An ecological model of social networks and community participation. Research in Developmental Disabilities, Vol. 38, p. 18-29. Doi: 10.1016/j.ridd.2014.10.008.

Socialinès apsaugos ir darbo ministerija. (2016-2017). Socialinis pranešimas 2016-2017. Prieiga internete: https://socmin.lrv.lt/uploads/socmin/documents/files/pdf/13488_socialinis-pranesimas-2016-17.pdf

Statistikos departamentas. (2019). Socialine apsauga. Prieiga internete: https://osp.stat.gov.lt/statistiniu-rodikliuanalize\#/.

Swanwick, R., Oppong, A. M., Offei, Y. N., Fobi, D., Appau, O., Fobi, J., Mantey, F. F. (2020). The impact of the COVID-19 pandemic on deaf adults, children and their families in Ghana. Journal of the British Academy, Vol. 8, p. 141-165. Doi: https://doi.org/10.5871/jba/008.141.

Valstybinio audito ataskaita. (2020). Asmenų su negalia socialinè integracija. Valstybés kontrolè, Nr. vae-9.

Zhao, X., Zhang, C. (2018). From isolated fence to inclusive society: the transformational disability policy in China. Disability \& Society, Vol. 33(1), p. 132-137. Doi: 10.1080/09687599.2017.1375246.

\section{THE ACCESSIBILITY OF SOCIAL SERVICES FOR PEOPLE WITH A PSYCHO-SOCIAL DISABILITY: THE CASE OF THE ANYKŠČIAI DISTRICT}

\section{Odeta Merfeldaitė, Gintarė Sabaliauskienė, Laura Gardziulevičienė}

\section{Summary}

The social integration of people with psycho-social disabilities is one of the most important issues in the fields of health and social security both in Lithuania and in European countries. It is noticeable that the paradigms of disability and inclusion come from more developed countries, which aim to adapt to the individual needs of people with disabilities, equality and fostering community solidarity. Living in a community gives people with a psycho-social disability the opportunity to live an independent life, and to be a full member of society.

Ensuring the provision of various social services is important for the successful functioning of people in the community with disabilities. Accessibility to social services for people with disabilities is considered to depend on the attitude and financial resources of the state's social policy-makers. Social services are part of the social security system. The purpose of these services is to restore a person's ability 
to take care of themselves, and to promote their participation in society when the person is unable to do so. The concept and goals of social services are focused on processes of helping the individual or his or her family. Social assistance processes do not happen by themselves, they depend on the attitude of the community, the social climate of the local population, the living environment, and the help of institutions.

In Lithuania, the provision of social services is regulated by laws, legal acts and other normative documents, which ensure the planning, organisation and formation of services, and the types and financing envisaged. Local government remains the main organiser of social services. But the contribution of society itself, the attitude towards people with psycho-social disabilities, is no less important. Therefore, a collective focus and cooperation are important to build social inclusion in society.

Processes of social inclusion in society reflect the state's maturity in taking care of the most vulnerable groups in the population. People with a psycho-social disability are members of society, and they should have the right to remain in their community, where they must be provided with full support from educational, training, health-care, employment and social services structures. The type, level and nature of the disability must be taken into account. For example, people with mild and severe psycho-social disabilities are most at risk of social isolation and exclusion, while people with moderate psycho-social disabilities like to form close friendships with others. People with psycho-social disabilities are more vulnerable and more at risk, experiencing social exclusion and facing unemployment and poverty.

The successful functioning of a person with a disability depends on complex factors, one of which is participation in labour market processes. In Lithuania, the integration of people with disabilities into the labour market is a major problem, and work is the basis for a person's successful functioning in society. According to the statistics, in 2019 the Disability and Working Capacity Assessment Service provided recommendations on the needs of $13 \%$ of people in Lithuania to receive assistance and special services (Public Audit Report, 2020).

More than 248,000 people with disabilities live in Lithuania, which accounts for almost $10 \%$ of the total population of the country (SADM, 2021). People with disabilities need help, and they need access to social services according to their needs, the organisation of which should be constantly improved, to expand the network of services provided. Although the participation of the disabled in the life of the community is widely discussed in the scientific discourse, the possibilities for access to social services in the community in the regions of Lithuania have not been studied. There is a lack of research to identify access to social services to meet the individual needs of a person with a psycho-social disability. 
Based on a case study of one Lithuanian area, the article examines the possibilities for people in the community with psycho-social disabilities to receive social services. The research will contribute to highlighting the quality of life of people with psycho-social disabilities, and to finding supportive measures and solutions for the full functioning of these people in public life. The objectives of the research: 1) to find out the possibilities for institutional assistance for people with psychosocial disabilities; 2) to identify problems in providing social services to people in the community with psycho-social disabilities; and 3) to analyse employment opportunities for people with psycho-social disabilities. The aim of the article is to show the possibilities for access to social services by people in the community with psycho-social disabilities, based on a case study. The research was conducted in the Anykščiai municipality.

The study found that people with psycho-social disabilities face many barriers in various areas due to their disability. The problems of integrating into the community people with psycho-social disabilities are related to social exclusion, negative public attitudes towards people with psycho-social disabilities, their own unpreparedness to participate in community activities, and the underdeveloped social infrastructure of the Anykščiai district. The study found that access to social services for people with psycho-social disabilities does not meet their needs. Institutional changes are also needed to increase the accessibility of services to meet the individual needs of people with psycho-social disabilities, and political decisions are needed at both state and municipal levels.

Our research has shown that inter-institutional cooperation is an important factor in the process of social inclusion, as cooperation in aid processes involves the community, responds to the needs of people with disabilities, and attracts more resources. It is obvious that the more stakeholders involved in the aid process, the more the idea of social inclusion is developed, and a positive community attitude is formed towards the person with a psycho-social disability.

Odeta Merfeldaitė - profesorè, daktarè (socialiniai mokslai - edukologija), Mykolo Romerio universiteto Edukologijos ir socialinio darbo institutas.

El. paštas: o.merfeldaite@mruni.eu 